\title{
Review of Fouseki, K. 2015. Dispute Management in Heritage Conservation: The Case of in situ Museums.
}

Yu-tz Tung 1 ,*

How to cite: Tung Y. 'Review of Fouseki, K. 2015. Dispute Management in Heritage Conservation: The Case of in situ Museums'. Papers from the Institute of Archaeology, 2019, 28(1): pp. 1-6. DOI: 10.14324/111.2041-9015.009

Published: 10/12/2019

\section{Peer Review:}

This article has been peer reviewed through the journal's standard double-blind review.

\section{Copyright:}

(c) 2019, The Author(s). This is an Open Access article distributed under the terms of the Creative Commons Attribution License (CC-BY) 4.0 https://creativecommons.org/licenses/by/4.0/, which permits unrestricted use, distribution and reproduction in any medium, provided the original author and source are credited • DOI: [https://doi.org/10.14324/111.2041-9015.009].

\section{Open Access:}

Papers from the Institute of Archaeology is a peer-reviewed open access journal.

*Correspondence: yu.tung.11@ucl.ac.uk

${ }^{1}$ National Cheng Kung University 


\section{BOOK REVIEW}

\section{Review of Fouseki, K. 2015. Dispute Management in Heritage Conservation: The Case of in situ Museums.}

Yu-tz Tung

Fouseki, K. 2015. Dispute Management in Heritage Conservation: The Case of in situ Museums. Oxford: BAR Publishing. 114 pages (Paperback). £22. ISBN 978-1-40731-439-6

This publication analyses archaeological site management in Europe, by closely dissecting the process undergone when disputes occur during the decision-making process to develop a solution to foresee or settle conflicts. The case studies are wellselected such that each stand for different scenarios of disagreements, allowing the readers to reflect on how factors such as goals, macro- and micro- contexts, competing interests, and value conflicts of the players affect the decision-making phase. The last part of the book enhances the analysis with a frame to settle or foresee disputes during the negotiation process. This step-by-step solution may be a new measure for future heritage managers to refer to while being involved in a heritage management process. The author gained her perspectives about the Acropolis Museum from her participation as an archaeologist in the museum construction organisation. This book is an enhanced version of her doctoral thesis. She has been devoted in a wide range of heritage topics, from museum exhibition and community participation to cultural heritage management. From her experience in Greece and the UK, it is certain that she would contribute a distinctive viewpoint with the heritage practitioners.

The beginning four chapters are an introduction to the research, methodology, and theoretical framework of dispute management and the chronological developments of archaeological heritage management in Europe. The theoretical review of dispute 
management methods provides interesting comparisons of the recognised heritage management models (e.g. the Burra Charter (Australia ICOMOS 1999) and the values-led management approaches by the Getty Conservation Institute (Mason 2002; Sullivan 1997). The author also draws references from social science fields to explore disputes in the heritage management process in three phases: its genesis, escalation, and resolution. The development of heritage management has pointed out four themes of disputes: authenticity/ethical recognitions in terms of presentation and the learning outcome, access/conservation, the adaptive use of the sites, and the aesthetics of the museum structures. The case studies presented are analysed according to these four themes to better categorise the process of disputes and solutions.

The case study chapters are presented in three sections, with Chapters Five and Six respectively dedicated to review and analysis of the decision-making processes of private developments and public work cases of local and national significance. Chapter Seven is the major case study that discusses the management process of the New Acropolis Museum that reaches an international level of stakeholder and values dispute. These are categorised into the four dispute themes in the discussion section. The case studies exemplify the heterogenous nature of involved authorities, social groups, professionals from architecture and archaeology, and individuals. Alliances may be formed by parties with similar goals and needs, yet each has their own agenda in the interplay, anticipating acquisition of benefits extending beyond the academic and heritage fields to political, social, and economic aspects. To complement the complexity of the major case study, the author refers to other case studies with similar problems to explore conflicts and decision-making processes. The unique contexts contributing to the value conflicts of these case studies make the comparisons quite difficult to be examined.

The author presents the management processes of the New Acropolis Museum chronologically and compares dispute management procedures to complement the insufficiency in heritage management framework. The dilemma in this case study demonstrates local and national value conflicts, as the readers may compare with Chapters Five and Six. The issues can be social, like an Orthodox church which was to be demolished for Parthenon marbles to be excavated, that drew religious and 
academic concerns. One other disagreement concerned the aesthetic value of the Acropolis, and whether the proposed museum was appropriate for the landscape and if the removal of vernacular structures or demolition of private housing was adequate. The expected function of the new museum was to assume national identity, yet to what extent should the recent historic heritage being preserved for a comprehensive sense of belonging to be demonstrated? The argument could be of international scale of repatriating the Parthenon sculptures from the British Museum, though the author does not refer to other examples at the international level.

Despite these case studies chapters being quite long and descriptive, the author has drawn out from her selection the complex social roles that heritage plays. The disagreements may be about the interpretation of artefacts, authenticity of the presentation, economic factors, and social developments, or political influences (Clark 2008; Gould and Burtenshaw 2014; Turner and Tomer 2013). The development-led excavations had drawn completely opposite attitudes about the in situ preservation from the general public. The case of the Rose Theatre and Jorvik Viking Centre demonstrated the public valuing heritage and rallying for it being preserved in situ. In this case, replacing car parks and open-square space with in situ museums had caused public distrusts, and created concerns about possible socioeconomic losses. The way archaeological evidences are presented and interpreted, result in different opinions being expressed by the professionals, benefactors, and public. In the cases of Jorvik Viking Centre and Aboa Vetus, academics voiced their concerns for the authenticity of interpretation. Yet the visitor feedback in the cases of Jorvik Viking Centre seemed to be quite effective in learning. The visitor comments of Mitropolis Museum at Naxos seemed to be quite positive despite replicas being exhibited.

Another issue is the adaptive use of heritage space. The expected roles of in situ museums are to enrich the quality of life, and establish a sense of identity for the public. However, the museum may risk commoditising the heritage places into tourist attractions, as is argued in the case of Jorvik Viking Centre, in which archaeologists doubted it's transformation into a theme park. The professionals argued about the presentation of the museum structures in the surrounding landscape, not only to the extent that museums should be integrated into the historic landscape, but also the 
materials used in museum construction, as demonstrated by the Naxos case. The disputes in these chapters span wide range, from local, in-between government agencies, to international challenges. Thus, negotiations take place at all stages and all contexts in the management process. These lead to more complicated stakeholder relationships and make conflict resolution more necessary.

The author provides approaches to dispute management from interdisciplinary perspectives in Chapter Eight. The previous management models or the step-by-step consensus building framework tend to recommend basic directions for the heritage managers (e.g. Australian ICOMOS 1999; Hall and McArthur 1998; Sullivan 1997; Smith 2009). These guides introduce managers to measures for involving stakeholders in building communication platforms, but not how to deal with a dispute situation. Figuring out the genesis to dispute seemed like the initial steps in most management models - exploring stakeholders' views about the management contexts, the power relations within the management frameworks, and the values and needs stakeholders attached to the sites. The causes of disputes may be, from stakeholders' understanding, the interrelations of involved parties, the values and needs attached by them, and the ways they compete with others' wishes, macro- and micro- management contexts, anticipated outcomes for site management, and the long-term relationships between the stakeholders. The author classifies the situations encountered during the management process into 'frames', with constants and variables at work that further develops the disputes to escalate or de-escalate them. These factors analyse each player's perspectives of the stakeholder interrelationships in the management process, enlightening managers to foresee possible disputes, recognising those with common interests to form alliances, and prepare for suitable ways of negotiation with groups adopting different styles and power levels. In the final section, the author provides a checklist with simple but comprehensive guidelines, tactics, and illustrations for each procedure. The author may have introduced an innovative complementary toolbox for the available heritage management approaches or principles to guide heritage managers in implementing strategies, and negotiating with stakeholders. Previous studies, especially, have put more stress on the planning process than dispute resolution. As the author states, these theoretical frameworks of dispute management have examined the cases studies within European contexts. However, only through more trials and reviews by 
heritage practitioners can these methods become more effective and applicable to be used in not only resolving disputes in heritage management but possibly in other disciplines as well.

This publication provides an insightful perspective of archaeological heritage preserved in situ around Europe. The case studies are not only detailed descriptions of the dispute situations, but reach a wide time-scape allowing the readers to reflect on the involvement of archaeological heritage conservation. The chapters of the book begin with theoretical management frameworks, developments of in situ museums, case studies in public and private developments, and move to the major case study of the New Acropolis Museum. The author has established a good flow to slowly bring the readers into discussion and concluded with the solution frame. The only criticism is that the results of the value conflicts between the macroenvironmental information and case studies are not specified in the chapters. The reader may want to know if these values can be compared in the same way. Despite that, this publication can be a worthwhile reference for heritage mangers during decision-making phases, or researchers when developing management approaches.

\section{REFERENCES}

Australia ICOMOS. 1999. The Burra Charter: the Australia ICOMOS Charter for Places of Cultural Significance. Available at: https://australia.icomos.org/wp-content/uploads/BURRA CHARTER.pdf [Accessed 17 August 2019].

Clark, K. 2008. Sustainability and heritage. in Fairclough, G, Harrison, R, Jameson, J H J \& Schofield, J. (eds.). The heritage reader. London: Routledge. pp. 82-98.

Gould, P G \& Burtenshaw, P. 2014. Archaeology and economic development. Public Archaeology 13: 3-9.

Hall, C M \& McArthur, S. 1998. Integrated heritage management: principles and practice. London: Stationery Office.

Mason, R. 2002. Assessing values in conservation planning: methodological issues and choices. in: de la Torre, M (ed.). Assessing the values of cultural heritage, Los Angeles: The Getty Conservation Institute: 5-30. 
Smith, S N. 2009. Consensus building for cultural heritage place management. in: Myers, D, Smith, S N, Ostergren, G (eds.). Consensus building, negotiation, and conflict resolution for heritage place management. Los Angeles: The Getty Conservation Institute: $24-61$.

Sullivan, S. 1997. A planning model for the management of archaeological sites. In: de la Torre, $\mathrm{M}$ (ed.). The conservation of archaeological sites in the Mediterranean region: an international conference organized by the Getty Conservation Institute and the J. Paul Getty Museum, 6-12 May 1995, Los Angeles: The Getty Conservation Institute: $15-26$.

Turner, M \& Tomer, T. 2013. Community participation and the tangible and intangible values of urban heritage. Heritage \& Society 6: 185-198. 